\title{
THE FUTURE OF THE NBL: REVIEWING THE PLAYER POINTS SYSTEM AND THE OVERALL SUSTAINABILITY OF THE LEAGUE
}

\author{
OLAF BORUTZ*
}

CONTENTS

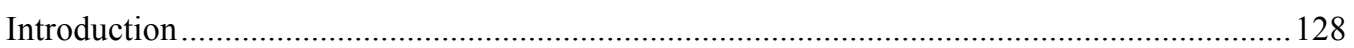

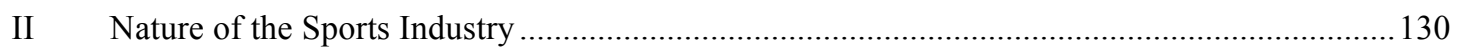

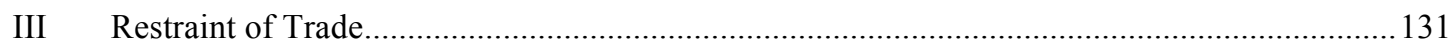

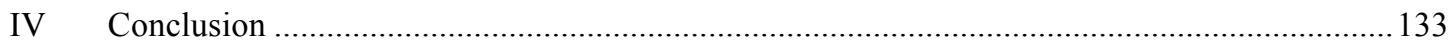

\section{INTRODUCTION}

This article reviews and responds to the analysis completed by Jacob Holmes in the primary article 'Professional Sport and Market Restrictions: Is the Player Points System in the Australian National Basketball League an Unfair Restraint of Trade?'. It focuses on Holmes's conclusion that the current Player Points System ('PPS') used by the National Basketball League ('NBL') effectively amounts to a restraint of trade and that an alternative adjunctive system, such as the Restricted Free Agency model employed by the Australian Football League ('AFL'), should be used to govern the entire NBL instead. While there is merit in Holmes's argument for the consideration of a new system to replace the PPS in the future, this article adopts the position that until such time as the NBL is able to sustain its current format and competition, no change should be made. It also argues that it is unlikely that the courts will in fact hold that the NBL's PPS System does amount to a restraint of trade, given its reasonable nature and overall objectives of developing an equal and level playing field for the entire sport.

The PPS operates in conjunction with a team salary cap (currently set at AUD\$1 000 000) ('Salary Cap') and the Marquee Player Rule to govern the

BA (CommMediaMgmt), LLB (University of South Australia); Associate for the W Group (WRP Legal \& Advisory and W Sports \& Media). 
teams competing in the NBL. Introduced prior to the 2003-04 season, and reviewed prior to the 2009-10 season, the system aims to ensure the NBL's effectiveness and sustainability. ${ }^{1}$ In the current system, each player is allocated a Player Points Ranking between one and ten, reflecting (where relevant) their performance in the NBL and/or other league for the previous season. Each club is allowed a total of 70 points for all players on the club's active roster, although Registered NBL Development players are exempt. ${ }^{2}$ In an effort to promote greater (including international) talent, however, the NBL adopted the Marquee Player Rule, which allows one player per club to be paid outside of the Salary Cap. Acting as a ranking system based on player's statistics, rather than a rating system, the PPS is independent from salary levels, bonus structures or representative opportunities. ${ }^{3}$ It faces yearly review and offers players an opportunity to appeal their ranking. ${ }^{4}$

In recent years, there have been doubts about the long-term sustainability of the NBL, especially in light of the financial difficulties of the Wollongong and Townsville clubs (both entering into voluntary administration). ${ }^{5}$ It has been noted that one of the biggest challenges facing the NBL is the current absence of a lucrative television broadcasting deal, particularly when compared with other Australian sporting codes, especially the Australian Football League (AFL): ${ }^{6}$

The problem for the NBL is that unlike its main competitors, the four football codes and cricket - there is no lucrative central broadcast rights deal which sends dollars down the line to the clubs. ${ }^{7}$

Accordingly, the sustainability of the league remains the NBL's biggest challenge. ${ }^{8}$ Although international interest in the NBL has increased, especially following James Ennis's and Josh Childress's successful seasons with the Perth Wildcats and Sydney Kings respectively, and the involvement

\footnotetext{
National Basketball League, Salary Cap and Player Points (25 August 2015) $<$ http://www.nbl.com.au/salary-cap-and-player-points/>.

3 Ian Smythe, 'Player Ranking System Delivers a More Exciting and Secure NBL', Sports Business Insider (online) 16 May $2012<\mathrm{http}$ //sportsbusinessinsider.com.au/blogsfeatures/crocs-ceo-ian-smythe-how-the-player-ranking-system-will-help-nbl-succeed/>.

5 Paul Suttor, 'NBL Can't Afford to Shut Down to Fix Woes but Six-Team Format a No-go Zone', The Sydney Morning Herald (online), 12 March 2015

$<$ http://www.smh.com.au/sport/basketball/nbl-cant-afford-to-shut-down-to-fix-woes-butsixteam-format-a-nogo-zone-20150312-142r0g.html>.

6 Note: this article was prepared prior to the announcement of the new television rights deal between Fox Sports Australia and the National Basketball League for the 2015/16 NBL season.
}

2 Ibid.

4 Ibid.

7 Ibid.

8 Ibid. 
of high profile Australian players (in some cases ex-NBL alumni) in the United States' National Basketball Association ('NBA') competition. This has resulted in the NBL 'becoming a legitimate destination for aspiring NBA players" ${ }^{9}$ and various high profile players seriously considering Australia as a destination for their basketball careers. To date, however, this has not translated into the NBL becoming a self-sufficient and high grossing commercial enterprise as a whole, despite the success of some individual clubs.

It is arguable, therefore, that the PPS is an important aspect of the NBL's future success, particularly considering its aims of allowing clubs 'equitable access to the available talent and nothing more'. ${ }^{10}$ For example, Ian Smythe, CEO of Townsville Crocodiles, has indicated that the PPS is successfully 'delivering more equitable access to the talent', ${ }^{11}$ which is providing a competitive league with the hope for a sustainable future, particularly for those smaller market teams (such as Townsville) who are unable to compete with the larger market teams (for example, Perth and Melbourne).

\section{NATURE OF THE SPORTS INDUSTRY}

The PPS is a creature of its sector and it reflects 'the unique economics of the sports industry' 12 that requires 'competitive equality'. ${ }^{13}$ Cook and Davies have noted that:

Sports leagues rely on mutual interdependence to maintain a sustainable competition since each individual has a vested interest in the economic viability of the other clubs. Hence, professional sports administrators govern, with a myriad of restrictions on the clubs and players, to provide stability for their organisation. ${ }^{14}$

On this basis, it is arguable that for the survival of the NBL, it must impose governance controls such as the PPS system, to avoid, for example, the situation in the Premier League in the United Kingdom where the wealthiest teams remain dominant year on year. This is a result of their ability to

9 Roy Ward, 'NBL Attracting NBA-Level Imports for New Season', The Sydney Morning Herald (online), 3 October $2014<\mathrm{http}$ //www.smh.com.au/sport/basketball/nbl-attractingnbalevel-imports-for-new-season-20141003-10ppv3.html $>$.

10 Smythe, above $\mathrm{n} 3$.

11 Ibid.

12 Justin Cook and Chris Davies, 'Free Agency and the Australian Football League' (2012) 24(2) Bond Law Review 64, 67.

13 Ibid 66.

14 Ibid. 
purchase all of the world's best players through the distinct lack of either an operational salary $\operatorname{cap}^{15}$ or an adjunctive system like the PPS. Additionally, while the purpose of the Salary Cap is to address this issue from a financial perspective, the PPS goes further to specifically address the skills and abilities of the players and not just their monetary worth, in an attempt to achieve equalisation across the sporting code. Lastly, when considering the well documented and regularly occurring examples of teams in various codes abusing and cheating the salary caps imposed on them (see, eg, the Melbourne Storm controversy in the National Rugby League ${ }^{16}$ and the Perth Glory controversy in the A-League ${ }^{17}$ ), the PPS may in fact be a necessary addition in a league that has struggled for sustainability, especially when considering the economic disparity and smaller markets of some of its teams.

\section{RESTRAINT OF TRADE}

There have been criticisms that the PPS is not only an 'unreasonable' restraint of trade but also 'a flagrant one'. ${ }^{18}$ Accordingly, in reviewing the common law position with respect to restraints of trade within the professional sports industry, it can be determined that the common law does in fact allow for a restraint of trade if it is not unreasonable, with the courts recognising 'the special nature of sporting competition and the necessity for sporting bodies to regulate such competition' ${ }^{19}$ Furthermore:

In restraint of trade cases involving sport, the judiciary has accepted that labour market controls are justified on the grounds that they protect the legitimate interest of the league, namely, competitive equality, financial viability and player retention. ${ }^{20}$

15 Matt Meir, 'New Premier League Financial Rules Further Alienate the 'Small Clubs', Metro UK (online), 8 June 2014 <http://metro.co.uk/2014/06/08/new-premier-league-financialrules-further-alienate-the-small-clubs-4753962/>.

16 National Rugby League, Melbourne Storm Breach NRL Salary Cap $<$ http://www.nrl.com/melbourne-storm-breach-nrl-salarycap/tabid/10874/newsid/58359/default.aspx $>$.

17 Dominic Bossi, 'Perth Glory Fined \$269,000 and Booted out of A-League Finals Series for Salary Cap Breaches', The Sydney Morning Herald (online), 10 April 2015

$<$ http://www.nrl.com/melbourne-storm-breach-nrl-salarycap/tabid/10874/newsid/58359/default.aspx $>$.

18 Brendan Schwab, 'NBL's Player Rating Points System is a Flagrant Restraint of Trade' Sports Business Insider (online), 20 August 2015

$<$ http://sportsbusinessinsider.com.au/news/category/financial-and-governance/brendanschwab-nbls-player-rating-points-system-is-a-flagrant-restraint-of-trade/ $>$.

19 Warren Pengilley, 'Sporting Drafts and Restraint of Trade' (1994) 10 Queensland University of Technology Law Journal 89, 97.

20 Cook and Davies, above n 12, 71. 
Thus, when determining whether a restraint of trade exists with respect to the PPS system, the court will consider the operation of the restraint ${ }^{21}$ as well as the facts of each individual case. ${ }^{22}$ On this basis, and given that the ranking system is based on the player's performance and statistics, it must be noted that the PPS is very different from other adjunctive systems used in the sports industry to regulate players. Furthermore, unlike many of the player transfer systems used in other sporting codes, the PPS does not impose a transfer fee, nor does it create difficulty in moving from one club to another, ${ }^{23}$ so long as the total team points allow it.

Following from this, even if a restraint of trade is able to be established, the rule or provision will only be valid and enforceable if it is 'reasonable' in the circumstances. $^{24}$ To be reasonable, the restraint must be designed to protect a legitimate interest, reasonable in the interests of all the parties, and in the public interest. ${ }^{25}$ It is well established that sports clubs have a legitimate interest in regulating sport and in balancing the ability of teams, given the nature of the sport industry. ${ }^{26}$

Legitimate interests for clubs are:

(1) protection of competition; $;^{27}$

(2) protection of the economic viability of a game and protection of its proper administration; ${ }^{28}$

(3) provision of a system of balance in the capacity of various clubs and development of team spirit; ${ }^{29}$

(4) ensuring a club's continued existence; $;^{30}$ and

$21 \quad$ Buckley v Tutty (1971) 125 CLR 353.

22 Kores Manufacturing Co Ltd v Kolok Manufacturing Co Ltd [1959] 1 Ch 108, 117 (Lord Jenkins).

23 Cf Hall v Victorian Football League [1982] VR 64.

24 Nordenfelt v Maxim Nordenfelt Guns and Ammunition Co Ltd [1894] AC 535, 565 (Lord Macnaghten); Adamson v New South Wales Rugby League Ltd (1991) 27 FCR 535, 568 (Hill J) ('Adamson').

25 Nordenfelt [1894] AC 535, 565 (Lord Macnaghten); Attorney-General (Cth) v Adelaide Steamship Co Ltd (1913) 18 CLR 30.

26 Adamson (1991) 27 FCR 535.

27 Foschini v Victorian Football League (Unreported, Supreme Court of Victoria, Crockett J, 15 April 1983).

${ }^{28}$ Greig v Insole [1978] 3 All ER 449, 496-7 (Slade J).

$29 \quad$ Buckley v Tutty (1971) 125 CLR 353, 377.

30 Beetson v Humphries (Unreported, Supreme Court of New South Wales, Hunt J, 30 May 1980), 19-20. 
(5) ensuring that teams fielded in a competition are as strong and well matched as possible. ${ }^{31}$

There is, therefore, a strong argument to be made that, even if the PPS does constitute a restraint of trade, it will be found to be reasonable, given its goal of promoting stability and sustainability in the NBL by creating 'competitive equality'. Although 'the restriction cannot impose a greater restraint than is reasonably necessary to protect the genuine interests of the controlling sporting organisation, ${ }^{32}$ there is merit in arguing that, given the current state of the NBL and the need for sustainability, as well as the nature of the sport industry and the breaches of salary caps common in other sporting codes, the PPS does not do so.

\section{CONCLUSION}

It is likely that the PPS is not an unreasonable restraint of trade, if it is even a restraint of trade at all. Rather, its most important factor is improving the sustainability of the NBL, which, as outlined above, is paramount at this stage. Once the goal of sustainability and equalisation across the NBL has been achieved, then there would certainly be merit in reviewing the system and adopting or modifying the rules to continue growing and developing the sport (eg, as seen in recent times with the introduction of the Marquee Rule). This could eventually extend to adopting a Restricted Free Agency model as utilised in both the AFL and the NBA. Ultimately, however, while the PPS may need further improvements to secure the sustainability of the NBL and should be continuously reviewed to ensure its suitability, the time for a significant overhaul is not yet at hand.

$31 \quad$ Buckley v Tutty (1971) 125 CLR 353, 377.

32 Cook and Davies, above n 12,71 . 